This item was submitted to Loughborough's Research Repository by the author.

Items in Figshare are protected by copyright, with all rights reserved, unless otherwise indicated.

\title{
Student interactions in the hidden curriculum
}

PLEASE CITE THE PUBLISHED VERSION

http://dx.doi.org/10.1177/1356336X16642189

\section{PUBLISHER}

Sage / ( The Author

\section{VERSION}

AM (Accepted Manuscript)

\section{PUBLISHER STATEMENT}

This work is made available according to the conditions of the Creative Commons Attribution-NonCommercialNoDerivatives 4.0 International (CC BY-NC-ND 4.0) licence. Full details of this licence are available at: https://creativecommons.org/licenses/by-nc-nd/4.0/

\section{LICENCE}

CC BY-NC-ND 4.0

\section{REPOSITORY RECORD}

Casey, Ashley. 2019. "Student Interactions in the Hidden Curriculum". figshare. https://hdl.handle.net/2134/20693. 


\section{Student interactions in the hidden curriculum}

Ashley Casey $^{\mathrm{ab}}$

${ }^{\text {a }}$ Loughborough University, UK

${ }^{\mathrm{b}}$ University of Limerick, IRE

\section{Corresponding Author}

Dr Ashley Casey

ZZ1.08 - Matthew Arnold Building

School of Sport, Exercise and Health Sciences,

Loughborough University,

Loughborough,

LE11 3TU,

UK.

Email: A.J.B.Casey@lboro.ac.uk

European Physical Education Review

Accepted for Publication - $9^{\text {th }}$ March 2016 
Running head: STUDENT INTERACTIONS IN THE HIDDEN CURRICULUM

\section{Student interactions in the hidden curriculum}

My brief, when invited to contribute the concluding article to this special issue, was to read a series of papers on learning through interaction and make comment. Trying to offer a perspective from outside of a special issue and apply it to a set of themed papers was not an easy undertaking. Different people and teams of people often translate a theme in very different ways and I was not privy to the discussions between editors and authors or between the authors themselves. Therefore it will not be surprising to hear that, when trying to position my argument, I jumped around a fair amount. I moved between Mosston's spectrum of teaching styles through models-based practice and then global education reform and its focus on macro rather than micro indicators of learning.

Ultimately in reading the papers again and focusing on what brought them together I was drawn to consider the multi-faceted ways in which "teaching and learning interact in complex, uncertain and unpredictable ways" (Amade-Escot, 2016: ?). Specifically, I was reminded of Ronholt's (2002) claim that hidden curricula are embedded within the ordinary and everyday exchanges that occur between teachers and students and between students. While none of the authors refer specifically to the hidden curriculum all of the papers, in different ways, can be seen to say something about it. For example, Wallhead and Dyson (2016) suggests that responsibility for learning is devolved, both intentionally and unintentionally, between teacher and students, while Barker and Quennerstedt (2016) used Foucauldian theory to elucidate the different ways in which the cultural context affects students' interactions and what is learned. 
Running head: STUDENT INTERACTIONS IN THE HIDDEN CURRICULUM

Of course, this is just my reading of the papers, tied to my own discursive history - one influenced by my work in models-based practice and as a teacher. But that is my point: how the papers are read will be in large part dependent on the reader's discursive background. Connections, relevance and meaning are made 'in the reading'. My impression is that regardless of whether the reader is interested in game-centred approaches (Harvey and Jarrett, 2014), issues of inclusion (Fitzgerald, 2005), movement competence (Evans, 2004), or any other topic that has attracted attention of physical education scholars, valuable insights into the nature of interactions in physical education can be gained from the papers in this special issue and it with that belief that I move forwards.

\section{Student interactions in the hidden curriculum}

Like the invisible bits of matter which occupy particle physicists, educators have detected and named a whole pantheon of shadow curricula that lurk, unseen, behind and beyond the content of daily lessons.

Dodds (1995, p. 91)

In naming a pantheon of "shadow curricula” Dodds drew on, and expanded, firstly Jackson's (1968) work around the hidden curriculum in mainstream education and secondly Bain's (1976) work bringing the hidden curriculum to physical education. Despite the prevalence of the term "hidden curriculum" in the vernacular of physical education it has not been extensively explored as a term or a construct. Given the paucity of research that explores the hidden curriculum specifically (even though the term is well used in the literature as a whole) it seems necessary to take a little time to describe key ideas before examining this special issue through this lens. Bain (1976: 154) described the hidden curriculum as being "comprised of unplanned and unrecognized values 
Running head: STUDENT INTERACTIONS IN THE HIDDEN CURRICULUM

taught and learned through the process of schooling.” More recently Casey and Quennerstedt (2015: 42) likened Dewey’s (1938) concept of collateral learning to the hidden curriculum, and asked if the most significant learning might be occurring collaterally while the "PE teacher is busy in the enterprise of teaching skills and subject content in the gym”.

Many have argued that these shadow curricula do a lot to teach students about social roles and social relationships through a series of structures that are found in schools but which mimic larger society and how it operates (c.f. Dodds, 1985; Jackson, 1968; Kirk, 1992; Rønholt, 2002). Dodds (1985) argued that political and economic influences, and social forces all affect and shape the nature of school and in turn teach the values, norms, rules and routines of social behaviour. Students learn how to be good workers i.e. obedient, prompt, adaptable, enthusiastic and persevering, and they learn these alongside their letters, words and numbers. They learn, in other words, how to be and become a certain kind of citizen (Evans, Davies and Wright, 2004; Gard and Wright 2001; Kirk and Macdonald, 1998; Öhman. 2010).

While many aspects of this learning are desirable, others might be considered undesirable. Some students learn to love games while others learn not to enjoy movement activities and instead find humiliation and embarrassment in their classrooms. However, this learning is not only school or teacher 'driven'. Students also support this learning through their own curricula and they often afford different status to different subgroups. Socio-economic background, skills levels and other characteristics play a part in defining the expectations of the students around physical education. In other words, students learn all sorts of things in addition to what teachers intend to teach. Dodds 
Running head: STUDENT INTERACTIONS IN THE HIDDEN CURRICULUM

(1985) suggests that there is a multi-level curriculum at play and the combined effect of these curricula result in the functional curriculum that students actually experience. In this way the curriculum is not a sterile and lifeless artefact that sit in a department's files or on noticeboards, but is a living and lived culture. Most particularly, and with regards to this special issue, the functional curriculum operates at a level where student interactions have a significant role to play on what is being learned.

In her consideration of the functional curriculum Dodds (1985) held that there are four levels of curriculum in simultaneous operation within any physical education lesson (Kirk, 1992). The first level of learning begins in the explicit curriculum that the teacher publically states, and in which learning is mapped out across lessons, units and years. This is what teachers want students to learn. It is, in the words of Kirk (1992: 40), "the level of curriculum that appears in school programs, syllabuses, and policy documents and that teachers consciously pursue.”

The second level of curriculum is the covert curriculum, which Dodds (1985) proposes refers to teachers “unspoken, non-public agenda” (p. 93). The covert curriculum is founded on teachers' expectations of behaviour and how students can and cannot work collaboratively and is rarely acknowledged in school or lesson documentation. The third level, the null curriculum, refers to what is not taught and what, therefore, cannot have an impact on students or allow them to show aptitude, ability or indeed inability. It is important to consider that what is not taught has a significant role to play in education, especially in positioning something as being important or not. Finally the fourth level, the hidden curriculum, "refers to the reflexive aspects of what teachers 
Running head: STUDENT INTERACTIONS IN THE HIDDEN CURRICULUM

say and do in organizing programs, writing lesson plans, and teaching classes” (Kirk, 1992: 40). This hidden curriculum is the unexamined or unexplained patterns or routines that teach students about importance for example registers, tests, picking teams and standing in silence.

The functional curriculum comes at the intersection of these other curricula but it is not, Kirk (1992) argues, the aggregate of its four levels. These levels do not so much add as distort, contradict and/or reinforce the messages that students receive from their teachers and their peers. Acknowledging these curricula, and considering the wider messages I drew from this special issue, it is my intention in the next section to explore the complexity of teaching and learning and give expression to some of the less obvious occurrences in physical education.

\section{Student interactions in the functional curriculum}

In their introduction Barker et al. (2016) explore current research on learning in and through interactions in physical education. These authors then, along with a number of the special edition authors, problematize the current practice of "providing students with opportunities to make decisions, work collaboratively, discuss content, and negotiate with one another to actively ‘construct meaning'” (p. ?). However, and as Johnson and Johnson (1999: 68) said with respect to Cooperative Learning, "seating people together and calling them a cooperative group does not make them one”.

Rather than accept that providing the opportunity is enough, Barker et al. (2016) ask the reader to challenge the assumption that 'asking' is enough and, in doing this, inadvertently mirror many of the discussions that were occurring forty years or more ago around hidden curriculum (see Jackson (1968) and Bain 
Running head: STUDENT INTERACTIONS IN THE HIDDEN CURRICULUM

(1976) for fuller debate). Both sets of discussions help us to remember that teachers' aspirations for physical education are not always realised in the lived experiences of their students. While we may - as in the case of Amade-Escot (2016), Brock and Hastie (2016) and Wallhead and Dyson (2016) - employ pedagogical models in an effort to enhance learning we must also be cognizant of what is happening away the direct presence of the teacher. Furthermore, as Öhman (2016) highlights, we need to be aware of how teachers’ decisions to employ avoidance-oriented strategies and self-regulate their actions when it comes to touch, impact and contribute to the construction and enactment of the functional curriculum. Finally, without stepping outside of our silos and “identifying connections and conceptual similarities and difference between current approaches” (Barker et al, 2016: ?) we fail to see the bigger picture that helps us, collectively and individually, to start discussions, problematize assumptions and guide future research.

What this special issue does so successfully is describe a variety of pedagogical situations thus allowing us to understand some of the ways in which stated curriculum intentions are metamorphosed in the functional curriculum. To expound my argument I draw on the didactic contract (Amade-Escot, 2016; Wallhead and Dyson, 2016) as a way of understanding the functional curriculum. Amade-Escot (2016: ?) conceptualises the didactic contract as "the set of negotiations, more often than not implicit between teacher and students, that specifically relates to the content at stake and that unfolds during participants' joint actions.” Similarly, Wallhead and Dyson (2016) position the didactic contract as a negotiation between teacher and students over whose responsibility it is to manage the task the teacher presents and what behaviours are or are not acceptable. The task, in the context of this paper, could 
Running head: STUDENT INTERACTIONS IN THE HIDDEN CURRICULUM

be considered as the explicit curriculum while the negotiations represents the covert, null and hidden curricula, both singularly and collectively. In this way the functional curriculum - like Wallhead and Dyson's (2016) explanation of the didactic contact represents the co-construction by teacher and students of "the forms of knowing, while knowledge itself is transformed through the pedagogical actions of both the teacher and student interactions” (p. ?).

While there is a body of research around the hidden and/or the functional curriculum there has been a lack of empirical work in this area. Like Barker et al. (2016: ?) I recognise that "the nature of interactions occurring during lessons has until recently escaped sustained empirical attention.” Rønholt (2002: 27) held that "a fairly ordinary exchange embeds a hidden curriculum, a hidden set of meanings and in some ways of participating in physical education.” When this exchange occurs away from the direct presence of the teacher (Brock and Hastie, 2016; Lafont et al. 2016) or when the teacher relies on asymmetric relations (Barker and Quennerstedt, 2016) or equally when "PE teachers' fears and growing uncertainties about physical contact with students” (Öhman, 2016: ?), then a short and apparently simple exchange between protagonists takes on new meaning. There is a need to consider and openly discuss issues that implicit and explicitly construct the functional curriculum and “achieve a more multifaceted understanding of...interactions in PE” (Öhman, 2016: ?).

Despite the apparent need to discuss the implicit and explicitly construct the functional curriculum, there is currently a focus in education policymaking and curriculum reform on 'big data'. This focus leads to a risk of missing the importance of individual exchanges in educating individuals rather than cohorts of children and young people. As Lafont et al. (2016) articulate, qualitative analyses of verbal 
Running head: STUDENT INTERACTIONS IN THE HIDDEN CURRICULUM

exchanges offer us a significant opportunity to add value to our understanding of the didactic contract, the functional curriculum and the interactive and active dynamics of pedagogical models such as Cooperative Learning. If Cooperative Learning - as an example of a pedagogical model used in this special issue - is capable of developing physical, cognitive, affective, and social learning in physical education (Casey and Goodyear, 2015) we need to consider the different interactions at play. Dodds (1985) - like Öhman (2016) - argued that political and economic influences, and social forces all affect and shape the nature of school and in turn teach the values, norms, rules and routines of social behaviour. And yet it is more than that. The minutiae of the didactic contract, the "initial proposals and actions which alter the learning milieu to initiate a breach in the didactic contract" (Wallhead and Dyson, 2016: ?), and "the indication that students in the middle-to-low skill homogeneous teams interacted more frequently than their counterparts in heterogeneous teams” (Brock and Hastie, 2016: ?) all serve as examples of how a construct such as the functional curriculum helps us to reconsider the importance of interactions. Kirk (1992: 53) concluded, "the term hidden curriculum has given us a start in terms of better understanding the dynamic of physical education teaching and learning.” In replacing 'hidden’ with 'functional' and considering the multifaceted interactions discussed and problematized in this special issue it becomes easier to see that we are a long way from understanding what is occurring in physical education.

\section{Concluding comments}

At this start of this piece I drew on the work of Dodds (1985: 91) to shine a light on the curriculum that "lurk, unseen, behind and beyond the content of daily lessons.” In concluding I am drawn to the work of Barker and Quennerstedt (2016) who argued that there is transience rather than fact built in to the assumptions we have about 
Running head: STUDENT INTERACTIONS IN THE HIDDEN CURRICULUM

teaching and learning in physical education. By changing the "equipment, location, music, activity, group size or constellation, instructions, performance format, or a combination of these example” (Barker and Quennerstedt, 2016: ?) we change power relations and shape "institutionalised habits and customs” which dictate what can be learned. By moving away from the curriculum as a single construct and acknowledging the habits and routines that drive teaching and learning we move beyond function and start to consider the possibilities that lay before us.

Education researchers, such as Barker and Quennerstedt (2016), have taken a Foucauldian turn to examine the ways "people talk about school and the wider world" (Collins and Apple, 2015). Collins and Apple (2015) suggest that such a turn allows researchers to consider school in "different ways and position students, educators and parents as different kinds of people” (p. 121). In arguing for a new economy of power Foucault (1982: 780) asked that we take "the forms of resistance against different forms of power as a starting point.” If we consider the functional curriculum, albeit crudely and in all probability rather naively, as what remains when all the different power relationships have played out then we might be able to mount what Foucault (1982: 780) described as “a series of oppositions” to what we find. Foucault argued that there was considerable opposition to the power of men over women and parents over children, for example, and yet the very fact that the hidden curriculum still works as a term in education speaks volumes of its prevalence in contemporary society. The importance of student interactions highlighted in this special issue provides us with an insight into what we are missing when different forms of power prevail in education. Only by exploring these small spaces and challenging the taken-for granted assumptions about what is being learned and what is influencing that learning can we begin to understand what is happening in schools. 
Running head: STUDENT INTERACTIONS IN THE HIDDEN CURRICULUM

\section{References}

Amade-Escot C (2016) Productive disciplinary engagement within didactical transactions: A case study of student learning in gymnastics. European Physical Education Review (Crossref to article in this special issue).

Bain LL (1976) Description of the Hidden Curriculum in Secondary Physical Education. Research Quarterly. American Alliance for Health, Physical Education and Recreation 47(2): 154-160.

Barker DM and Quennerstedt M (2016) Power and group work in physical education: A Foucauldian perspective. European Physical Education Review (Crossref to article in this special issue).

Brock SJ and Hastie P (2016) Student's verbal exchanges and dynamics during Sport Education. European Physical Education Review (Crossref to article in this special issue).

Casey A and Goodyear VA (2015) Can Cooperative Learning Achieve the Four Learning Outcomes of Physical Education? A Review of Literature Quest 67(1): 56-72.

Casey A and Quennerstedt M (2015) “I just remember rugby”: Remembering Physical Education as More Than a Sport. Research Quarterly for Exercise and Sport 86(1): 40-50.

Collins R and Apple MW (2015) Can Neo-Marxian and Poststructural Theories in Education Inform Each Other? Using Genre Approaches to Bridge the Gap. In: Markee M (ed.) The Handbook of Classroom Discourse and Interaction. Oxford: Wiley Blackwell, pp. 115-127.

Dodds P (1985) Are hunters of the functional curriculum seeking quarks or snarks? Journal of Teaching in Physical Education 4: 91-99.

Evans J (2002) Making a Difference? Education and 'Ability’ in Physical Education. European Physical Education Review 10(1): 95-108.

Evans J, Davies B and Wright J (2004) Body knowledge and control. Studies in the sociology of physical education and health. London: Routlege/Falmer.

Fitzgerald H (2005) Still feeling like a spare piece of luggage? Embodied experiences of (dis) ability in physical education and school sport. Physical Education and Sport Pedagogy 10(1): 41-59.

Foucault M (1982) The Subject and Power. Critical Inquiry 8(4): 777-795 
Running head: STUDENT INTERACTIONS IN THE HIDDEN CURRICULUM

Gard M and Wright J (2001) Managing Uncertainty: Obesity Discourses and Physical Education in a Risk Society. Studies in Philosophy and Education 20: 535549.

Johnson DW and Johnson RT (1999) Making cooperative learning work. Theory Into Practice 38(2): 67-73.

Harvey S and Jarrett K (2014) A review of the game-centred approaches to teaching and coaching literature since 2006. Physical Education and Sport Pedagogy 19(3): 278-300.

Kirk D (1992) Physical education, discourse \& ideology: bringing the hidden curriculum into view. Quest 44(1): 34-56.

Kirk D and Macdonald D (1998) Situated learning in physical education. Journal of Teaching in Physical Education, 17: 376-387.

Lafont L et al. (2016) How to structure group work? conditions of efficacy and methodological considerations in PE. European Physical Education Review (Crossref to article in this special issue).

Öhman M (2010) Analysing the direction of socialisation from a power perspective. Sport, Education and Society 15(4): 393-409.

Öhman M (2016) Losing touch - Teachers’ self-regulation in physical education. European Physical Education Review (Crossref to article in this special issue).

Rønholt H (2002) 'It's Only the Sissies ...': Analysis of Teaching and Learning Processes in Physical Education: A Contribution to the Hidden Curriculum. Sport, Education and Society 7(1): 25-36.

Wallhead T and Dyson B (2016) A didactic analysis of content development during cooperative learning in primary physical education. European Physical Education Review (Crossref to article in this special issue). 